https://helda.helsinki.fi

\title{
Public opinion on useful languages in Europe
}

\section{Pietiläinen, Jukka}

2011

Pietiläinen , J 2011 , ' Public opinion on useful languages in Europe ' , European Journal of Language Policy, vol. 3 , no. 1 , pp. 1-14 .

http://hdl.handle.net/10138/26490

acceptedVersion

Downloaded from Helda, University of Helsinki institutional repository.

This is an electronic reprint of the original article.

This reprint may differ from the original in pagination and typographic detail.

Please cite the original version. 
European Journal of Language Policy 3.1 (2011), 1-14

\title{
Public opinion on useful languages in Europe
}

\author{
Jukka Pietiläinen \\ University of Helsinki, Finland \\ jukka.pietilainen@helsinki.fi
}

\begin{abstract}
This article analyses the results of five Eurobarometer surveys (of 1995, 1997, 1998, 2000 and 2005) designed to measure which languages Europeans consider most useful to know. Most Europeans are of the opinion that English is the most useful, followed by French and German. During the last decade the popularity of French and German as useful languages has been decreasing significantly, while English has remained universally favoured as the most useful language. French and German have lost their popularity especially among those who do not speak them as a foreign language. On the other hand, Spanish, Russian and other languages (often these include languages of neighbouring countries, minority languages or a second official language of the country in question) have kept and even increased their former level of popularity. Opinions about useful languages vary according to a respondent's knowledge of languages, education and profession. This article analyses these differences and discusses their impact on the study of foreign languages and the future of the practice of foreign languages in Europe.
\end{abstract}

Keywords: Foreign languages, European Union, public opinion, useful languages, English, French, German

The language policy of the European Union is based on the equality of all official languages and on multilingualism. The EU Commission has set a goal for every European to learn two foreign languages in addition to their native language (CoEC 2005). This official view has been criticised as being problematic because the popularity of English has reduced the interest in learning a second foreign language - for example in Sweden (Cabau-Lampa 2007) - or because it may actually "strengthen the hegemony of languages having more symbolic capital" (Tender and Vihalemm 2009: 59). Moreover, Europeans give only cautious support to this goal: in 2005, 50 per cent of Europeans agreed with the view that everyone in the EU should be able to speak two languages in addition to their mother tongue, while 44 per cent of respondents were against this option (CoEC 2006: 55).

In practice, the equality of languages has often been compromised by the use of a single language - English - for reasons of efficiency and to avoid costly 
translations (Phillipson 2003; Kraus 2008). English has gained the position of a lingua franca, which has reduced the status of previously important languages such as French and German. The share of documents produced by the European Commission originally in English has risen from 40 per cent in the 1990s to 75 per cent in 2010, while the share of those originally in French has fallen from 40 per cent to 8 per cent and in German from 5 per cent to below 3 per cent (Truchot 2002; Quartremer 2010). Informal linguistic practices seem to be undermining the formal principles of the EU. This development has been both severely criticised (Phillipson 2008) and welcomed with reservations (van Parijs 2004).

The purpose of this article is to describe the attitudes of Europeans towards "useful foreign languages", and analyse the changes in these attitudes. On this basis certain conclusions may be drawn as to the use of foreign languages in Europe in the future. The source data for this article is the Eurobarometer surveys, ${ }^{1}$ which have included questions about the "most useful" languages in 1995 (Eurobarometer 44.0), 1997 (Eurobarometer 47.0), 1998 (Eurobarometer 50.0), and in the special language-related Eurobarometer in 2000 (Eurobarometer 54LAN), as well as 2005 (Eurobarometer 64.3). Unfortunately similar survey questions have not been included in Eurobarometers since 2005. Although this basic data is generally available to researchers, the Eurobarometer data has only seldom been used as the basis for research. Even special studies on this subject (e.g. Ikonomu 2008) have not used the original data, just the published reports (e.g. CoEC 2006). The few exceptions include, for example, a study on potential language choice between EU citizens (Labrie and Quell 1997), a study on the linguistic capital of EU citizens (Gerhards 2008, and a study on changes in the foreign language skills of Europeans (Pietiläinen 2007).

This article uses the data from Eurobarometer 64.3 (material collected in November and December 2005) as its main source. This survey was conducted in all EU countries, including Romania and Bulgaria, which were candidate countries at that time but have since joined (in 2007). The data sample is taken from 1,000 respondents in each country, with some exceptions. The responses are weighted in such a way as to represent the entirety of the EU's 27 countries.

In this article special attention will be paid to the differences in the status of languages, based on the opinions expressed in response to the question 'Which two foreign languages are the most useful to learn?'. Moreover, it aims to find

\footnotetext{
${ }^{1}$ (See CoEC Eurobarometer). The data for Eurobarometer 64.3 was given for this research by Finnish Social Science Data Archive (http://fsd.uta.fi, accessed 19.3.2010). Other data has been downloaded from German Social Science Infrastructure Services (GESIS, http://www.gesis.org , accessed 19.3.2010), where questionnaires and information about Eurobarometer surveys can also be found.
} 
out how the popularity of foreign languages has changed in the European Union since the middle of the 1990s, and to look for background factors which may have had an impact on opinions of the usefulness of languages. Public attitudes to languages are based on how each individual assesses the communication potential of foreign languages. Opinions about the popularity of languages also have an impact on language learning: in some countries the choice to learn a foreign language is made on an individual basis (although the languages available in a particular school might be limited), while popular opinion has a role in deciding which languages should be learned.

\section{Theoretical background and former research}

The reasons people have for learning foreign languages have been explored on the basis of game theory (Laitin 1988; 1993; Selten and Pool 1995; Ginsburgh et al. 2007). These models are often simplified and they are rarely based on real data about foreign language skills. They have also been rather theoretical, with high levels of idealisation, and usually involve analysis of only bilingual models.

The role of elites in promoting a given foreign language has been indicated (Laitin 1988), and it has been shown that historical factors play a role in explaining the share of people who learn a foreign language (Ginsburgh et al. 2007: 346).

Other studies have paid attention to status differences among European languages (Hjorth-Andersen 2006; Van Els 2005; Swaan 1993; Ammon 1991). The status of English has usually been considered the highest, while French and German "may retain important functions in regional communication", and all national languages "will retain their functions in domestic society" (Swaan 1993: 251-52). The area of foreign language learning and language choice has also been explored by combining linguistics with economics (Grin 2003). Labrie and Quell (1997) have further shown that English has increasingly become the most likely language of communication between nationals of different European states. Foreign language competence is higher in more modernised countries (for example, Germany compared with Spain or Turkey), in smaller countries and countries in which English is not a mother language, and among people of higher social class and higher cultural capital (Gerhards 2008: 22-24).

Several studies (Coleman 2009; Macaro 2008) have pointed out declining interest in learning foreign languages in English-speaking countries. The dominance of English "has meant that monolingual English speakers are increasingly secure and complacent in their monolingualism" (Reagan 2004: 230). 
Popularity of foreign languages in general

Most Europeans agree that knowledge of foreign languages is "very useful": 54 per cent of respondents were of this opinion in 2005 (CoEC Eurobarometer 64.3). Moreover, 29 per cent agreed that knowledge of foreign languages is fairly useful, while only 8 per cent thought it was not very useful and the same percentage ( 8 per cent) saw it as "not useful at all". In comparison with the year 2000 (only old member states included) ${ }^{2}$ the opinion that knowledge of foreign languages is "very useful" has increased from 45 per cent to 54 per cent. The highest increase was seen in Germany, Italy and The Netherlands, while opinion about the usefulness of foreign languages decreased in Greece. Across Europe, a similar level of increase was observed across all age groups except for the youngest, among whom the percentage remained at its previously very high level.

The respondent's mother tongue has an impact on the opinion of the usefulness of foreign language skills. Among the native speakers of major languages like English, German, Spanish, French and Polish, about half (47-58 per cent) thought that foreign language skills are very useful, while native speakers of Dutch (67 per cent), Finnish (62 per cent) and Bulgarian (79 per cent) thought that knowing foreign languages is very useful. On the other hand, a significant number of native speakers of Portuguese (15 per cent) and Greek (16 per cent) think that knowing foreign languages is not useful at all.

Naturally, those who already know a foreign language think that knowing a foreign language is very useful. Of those who speak at least one foreign language, 67 per cent think that knowing a foreign language is very useful; of those who know at least three foreign languages, as many as 80 per cent think so. Almost 40 per cent of those surveyed who did not speak foreign languages were of the opinion that they are very useful. In larger countries like Germany, France, Italy, Spain and the UK, as well as Ireland as an English-speaking country, respondents who did not speak foreign languages were more inclined to think that they were not very useful.

\section{The most useful languages}

According to 78 per cent of those who do not speak English as their native language, English is the most useful foreign language. French and German follow, receiving almost equal shares. The fourth most useful language is Spanish,

\footnotetext{
${ }^{2}$ In this article "old member states" refers to the member states in the year 2000, the so-called "EU15", while "new member states" refers to the twelve countries that joined the EU in 2004 and 2007.
} 
Table 1. The most useful languages in $2005, \%$ of the whole EU population (in brackets $\%$ of those who do not speak the language in question as a native language). A choice of two languages was possible.

\begin{tabular}{lccc}
\hline & EU in total & Old member states & New member states \\
\hline English & $68(78)$ & $68(81)$ & 69 \\
French & $25(28)$ & $29(34)$ & 12 \\
German & $22(27)$ & $18(22)$ & 40 \\
Spanish & $15(17)$ & $19(21)$ & 3 \\
Italian & $3(4)$ & $3(4)$ & 4 \\
Russian & 3 & 2 & 9 \\
Some other language & 7 & 11 & 5 \\
None & 10 & 9 & 15 \\
Refused to answer & 6 & 6 & 6
\end{tabular}

Source: CoEC Eurobarometer 64.3 (2005).

while Italian and Russian follow with much smaller scores, along with some other languages (Table 1). Other languages Europeans considered useful as foreign languages were Chinese (1.6 per cent), Dutch (0.8 per cent, especially in Belgium) and Arabic (0.7 per cent, mostly in Italy and Britain). Chinese, despite its low rating, has almost doubled its popularity as a useful language since 1995 in the old member states, and its prominence may well have further increased since 2005.

Opinions about the usefulness of different languages vary a lot in different parts of Europe. In 2005 between 70 per cent and 97 per cent of the population in almost all European member states thought that English was one of the two most useful languages. Only in Luxembourg did a minority find English useful (37 per cent), mainly because German and French already occupied the two possible choices. In English-speaking countries the language considered most useful is usually French. In southern and western Europe the second most frequently mentioned useful language after English is French, while German takes second place in eastern and northern Europe.

Especially interesting is the situation concerning linguistic minorities and majorities in countries with large linguistic minorities. In Estonia and Latvia, both the Russian speakers and the Estonian/Latvian speakers find the language of the other group useful in approximately the same proportions. In Finland and Belgium an asymmetry appears: in Finland, the Swedish-speaking minority finds Finnish more useful (59 per cent compared with 32 per cent) than the Finnish-speaking majority finds the Swedish language. In Belgium, the Dutch speaking population sees French as useful (86 per cent), while the French-speaking part of the population sees Dutch in this role less commonly (56 per cent). 


\section{Trends of change}

From 1995 to 2005 the most important change in the popularity of languages (Table 2) was that the perceived usefulness of German decreased significantly; in old member states Spanish was mentioned as useful more often than German. The popularity of English decreased, but this is explained by the fact that there was an increase in the number who refused to give their opinion or chose

Table 2. Languages which respondents considered useful to know in addition to their mother language (\% of those who do not speak the language in question as their mother language)

In the fifteen old member-states

\begin{tabular}{lccccc}
\hline & 1995 & $1997 *$ & 1998 & 2000 & 2005 \\
\hline English & 94 & 93 & 83 & 90 & 81 \\
French & 52 & 54 & 44 & 47 & 34 \\
German & 45 & 46 & 34 & 30 & 22 \\
Spanish & 16 & 16 & 16 & 20 & 21 \\
Russian & 2.4 & 2.2 & 1.8 & -- & 1.9 \\
Italian & 2.1 & 3.1 & 2.4 & 3.5 & 3.5 \\
Dutch & 0.7 & 1.0 & 0.9 & 1.1 & 1.1 \\
Chinese & 1.2 & 1.3 & 0.9 & 1.3 & 2.0 \\
Japanese & 1.6 & 1.6 & 1.0 & -- & -- \\
Arabic & 0.6 & 0.6 & 0.3 & 0.6 & 0.9 \\
Sign language & -- & -- & -- & 1.0 & -- \\
Some other language & 1.6 & 2.0 & 2.2 & 3.9 & 7.7 \\
None & -- & -- & -- & -- & 9 \\
Refused to answer & 3 & 3 & 14 & 9 & 6 \\
\hline
\end{tabular}

* Native language was not asked. Counted on the basis of estimation of native language speakers.

Sources: CoEC Eurobarometers 44.0, 47.0, 50.0, 54LAN, 64.3.

In the twelve new member-states

\begin{tabular}{lccc}
\hline & 2001 & 2002 & 2005 \\
\hline English & 89 & 89 & 69 \\
French & 17 & 19 & 12 \\
German & 62 & 59 & 40 \\
Spanish & 3 & 3 & 3 \\
Russian & 8 & 8 & 9 \\
Italian & 3 & 4 & 3 \\
Chinese & 0.2 & 0.2 & 0.1 \\
Arabic & 0.3 & 0.1 & 0 \\
Japanese & 0.2 & 0.2 & -- \\
Some other language & 5 & 5 & 5 \\
None & -- & -- & 15 \\
Refused to answer & 1 & 1 & 6
\end{tabular}

Sources: Candidate countries Eurobarometers 2001:1 and 2002:2, and Eurobarometer 64.3. 
the newly introduced option of maintaining that no foreign language is useful to know. French was also among the losers, while the popularity of "some other language" (other than the nine or ten most popular languages) increased significantly in old member states.

In 2005 the share of non-responses grew because the question was formulated differently. It asked which language was useful for their "personal development and career" and added an alternative to choose: "none". The decline in popularity of the three main languages may have taken place due to previous pressure put on people by pollsters to reply to this question.

In any case, the order of languages remained the same, although the three most often mentioned languages lost in popularity. It is worth noting that German and French lost more of their share than English. On the other hand, Spanish and other languages, such as Chinese and Arabic, received more interest. Also the category "some other language" gained rapidly in favour. In many cases this most likely implied "some other regional language". The popularity of German and French decreased in almost every country, but especially where they were relatively unpopular previously. In Sweden, Finland, Greece, Portugal, Italy, Britain and Ireland opinions about the usefulness of both French and German decreased. Only in The Netherlands and Denmark did the popularity of German maintain the same level, while in Luxembourg it even increased. French preserved its popularity rate only among Dutch speakers in Belgium.

\section{Language skills and popularity of languages}

In general, opinion on the usefulness of a language is correlated to the number of speakers of that language as a foreign language in a given country. Almost all who speak English as a foreign language think that it is one of two most useful languages, while a major proportion of those who speak Chinese, German, French or Spanish as a foreign language think they are useful (Table 3). Many other languages, such as Italian, Russian and Arabic, are not listed even by those who can speak those languages.

Some smaller languages, such as Czech, Slovak and Croatian, are not even considered useful by those who can speak them. These languages are spoken as a foreign language mainly in the Czech Republic (Slovak), Slovakia (Czech) and Slovenia (Croatian), in which the most useful languages are usually English and German. On the other hand, Estonian, Latvian and Lithuanian are often considered useful foreign languages by those who speak them, because they are spoken as foreign languages mainly in countries in which these languages are 
Table 3. The impact of language skills on popularity of most often mentioned useful languages (\% of those who do not speak the language as a mother language)

\begin{tabular}{llll}
\hline & Speaks that language & $\begin{array}{l}\text { Does not speak } \\
\text { that language }\end{array}$ & Total \\
\hline English & $94 \%$ & $69 \%$ & $78 \%$ \\
German & $62 \%$ & $23 \%$ & $29 \%$ \\
French & $59 \%$ & $21 \%$ & $26 \%$ \\
Spanish & $61 \%$ & $12 \%$ & $15 \%$ \\
Russian & $31 \%$ & $2 \%$ & $3 \%$ \\
Italian & $35 \%$ & $2 \%$ & $3 \%$ \\
Chinese & $73 \%$ & $2 \%$ & $2 \%$ \\
Dutch & $47 \%$ & $0.5 \%$ & $0.8 \%$ \\
Arabic & $32 \%$ & $0.6 \%$ & $0.7 \%$ \\
Swedish & $36 \%$ & $0.3 \%$ & $0.5 \%$ \\
Polish & $28 \%$ & $0.3 \%$ & $0.5 \%$ \\
\hline
\end{tabular}

Source: Eurobarometer 64.3

official. Also in these countries knowledge of the state language has strong connections with the opinion of its usefulness: in Estonia, of those Russian speakers who speak Estonian, as many as 73 per cent see it as useful, while only 44 per cent of those who do not speak Estonian think that Estonian is useful.

In the enlarged European Union the position of the English language as "the most useful language" is unprecedentedly high, while German and French are in second place on rather equal terms. French is more popular in southern and western Europe, while German is more popular in northern and eastern Europe. Opinions about which languages are useful certainly have a strong impact on which languages are learned, which means that English will likely preserve its position as the most spoken foreign language in Europe.

As has been said, the position of German and French as useful languages fell. This was mainly because they lost popularity among those who did not speak them as foreign languages. In 1995 the number of those who did not speak French but thought it one of the two most useful languages was 51 per cent in the EU member states of that time; in 2005 the same figure in those countries was only 28 per cent. Among those who spoke French as a foreign language this drop was marginal, from 61 per cent to 59 per cent. Among those who spoke German, the opinion of its usefulness remained at 56 per cent both in 1995 and 2005, while among those who did not speak German it dropped from 44 per cent to 16 per cent. At the same time Spanish increased its popularity among those who already spoke it from 52 per cent to 58 per cent, and preserved its position among those who did not speak it at the level of 13-14 per cent. 
Factors influencing the popularity of languages

Socio-demographic variables make mainly small differences to the popularity of languages. The most important differences appear in the case of English and among those who think that no foreign language should be learned (Table 4). Professional status has some impact on opinions of the usefulness of individual languages. English was seen as one of the two most useful languages by 90 per cent of managers and 81 per cent of workers. French and Spanish also enjoyed more support among people with higher professional status, while German had the same popularity among almost all professional groups.

Those who enjoyed a longer period of education tend to see knowledge of foreign languages as more useful than those who ended their schooling at an earlier age. Actually, the lower popularity of English among people with a lower education is related to the fact that one-third of this group considers no language to be useful at all, or refuses to reply.

The more foreign languages people speak, the more often do they consider English to be one of two top useful languages. Also, the popularity of smaller languages increases with the knowledge of several languages: among those who spoke three or more languages, a significant number saw smaller languages, such as regionally important languages, as more useful than the major languages they could also speak. Those who did not speak foreign languages more frequently considered there to be no useful foreign languages, or refused to reply.

In any case, the strongest indicator of the opinion that English is one of the two most useful languages is a knowledge of English. When those who cannot speak English are analysed separately, it becomes clear that knowledge of many other languages in fact decreases the popularity of English as one of the most useful languages. The popularity of English is so high in any case, that even 60 per cent of those who can speak three foreign languages, but not English, see English as one of the two most useful languages.

Table 4. Correlations between useful languages and socio-demographic variables

\begin{tabular}{lcccccc}
\hline & English & German & French & Spanish & Other & None \\
\hline Professional status $^{\mathrm{a}}$ & .10 & .02 & .06 & .05 & .03 & -.09 \\
Age & -.30 & -.07 & -.04 & -.05 & -.03 & .24 \\
Education & .19 & .01 & -.04 & -.04 & .02 & .00 \\
Language skills & .19 & .11 & .06 & .04 & .09 & -.21 \\
Place of residence & .09 & .01 & .04 & .03 & .01 & -.07 \\
\hline
\end{tabular}

a. Only those working. ${ }^{\text {b. }}$ Place of residence: $1=$ Rural areas, $2=$ Small or middle-sized towns, 3= Large towns Source: Eurobarometer 64.3. Because of large amount of cases all correlations are significant. 
Living in a big city increased the likelihood of a respondent considering English to be one of the two most useful languages. In rural areas more people think that no foreign language is useful. The data also shows that younger population groups found English more useful than older population groups. German, French and Spanish are more popular among younger Europeans than among older respondents, but the differences are not so big. Older people tend to see no language as useful, or refuse to answer.

The actual knowledge of foreign languages has a different impact on the opinions of different age groups. More than older people, young people, even if they do not speak English as a foreign language, see English as one of the most useful languages.

\section{Conclusions}

The results of the above analysis of the Eurobarometer survey data indicate rather interesting trends. One of them is the increasing dominance of English as "the useful language", while on the other hand the data show that the popularity of smaller and middle-sized languages has also increased. Moreover, the widespread popularity of English is due not just to those who speak it already, but even more so to the opinions of those who do not speak it. When respondents are asked which language it would be most useful for children to learn at school, the rating of English is higher still. On the other hand, this development has not undermined the opinions of native English speakers about the usefulness of foreign languages. Almost in equal proportions to native speakers of other major European languages, they hold that to know foreign languages is very useful, and their foreign language skills are not much lower than those of speakers of other major European languages.

German and French have lost a great part of their popularity as languages that are considered useful. While their popularity has decreased in almost every country of Europe, this has happened especially in countries in which the role of these languages is secondary. Spanish has preserved its position as a useful language and even strengthened it. It is likely that the popularity of holidays in Spain may explain that, as well as the increased global role of Spanish. Based on game theory model by Selten and Pool (1991), Ginsburgh et al. (2007: 346) consider that the Spanish "should attract Europeans much more than it currently does", and it is possibly increasing its perceived usefulness in line with this. Moreover, the popularity of other globally important languages such as Chinese and Arabic has increased, even if their popularity in Europe is still low. 
Furthermore, other European languages, such as the language of neighbouring countries or the second official language of a country (next to the respondent's mother language) have done quite well in maintaining their popularity.

In practice, knowledge of all foreign languages has been increasing, while knowledge of English has been increasing more rapidly than knowledge of other foreign languages (Pietiläinen 2007). Aside from the dominance of English, a significant number of the people surveyed see regional or nationally important languages (such as large minority languages and second official national languages) as useful languages. The increasing role of such minority languages has also been confirmed by the adoption of the European Charter for Regional and Minority Languages in 1998 (Ikonomu 2008: 109). Languages in the middle are losing their importance because on the one hand English continues to gain prominence as the language of international communication, while on the other, smaller languages which play a local and regional role are gaining ground. In the competition between French, German and Spanish, the latter has succeeded best. Possibly the strong role of English as a lingua franca implies that more space opens up for smaller languages which have not lost their local importance. French and German, which once were able to compete with English on the larger scale, have remained important languages only in some parts of Europe. Moreover, competence in English is now such a widespread skill that those who do not know it are disadvantaged.

Nevertheless, "on its own [English] does not secure advantage" (Wright 2009: 113). This makes other foreign languages perhaps even more important than previously.

It is difficult to say what might have happened in the popularity of languages since 2005, when the most recent survey question on this topic was carried out. It is likely that English will have preserved its dominant position, while the smaller and middle-sized languages may have become more popular at the cost of German and French. The interest in non-European languages such as Chinese and Arabic have perhaps continued to increase.

Looking at the data, one sees that individuals' choice of a second foreign language has become more varied: some choose to study Japanese or Esperanto, while some find Russian or Italian more useful. Living in Estonia naturally makes Estonian one of the most useful languages, and in Catalonia the role of Catalan has become more important. There is almost limitless choice (see also Kelly 2009: 4). Opinion on which languages (aside from English) are most useful has become more fragmented, while the leading role of English has remained and even grown in the face of its most significant rivals. It seems that 'on the ground', the game of language choice cannot be simplified, because the usefulness of any language varies according to geographic and socio-demographic 
factors. In many cases the most successful strategy is considered to be to learn English because it has the widest communicative potential. On the other hand, a similarly successful strategy is considered to be to learn the most important regional language, which appears to be German or French only in rather limited and decreasing areas of Europe.

In practice, the future languages of preference of Europeans will likely be 1) their mother tongue, 2) English, and 3) a third language chosen on the basis of the language situation in their region, such as a language of a neighbouring country or one which is of personal interest. Therefore, the goal of the EU Commission is likely to work out in practice as: 'mother tongue plus English plus some other language'.

\section{Works Cited}

Ammon, U. (1991). 'The Status of German and other Languages in the European Community', in F. Coulmans (ed.), A Language Policy for the European Community. Prospects and Quandaries (Berlin: Mouton de Gruyter), pp. 241-54.

Cabau-Lampa, B. (2007). 'Mother Tongue Plus Two European Languages in Sweden: Unrealistic Educational Goal?', Language Policy 6.3-4: 333-58.

CoEC (Commission of the European Communities) (2001). Candidate Countries Eurobarometer 2001.2 (Brussels: European Commission) (electronic material).

—, (2002). Candidate Countries Eurobarometer 2002.2 (Brussels: European Commission) (electronic material).

—, (2005). 'A New Framework Strategy for Multilingualism'. Communication from the

Commission to the Council, The European Parliament, The European Economic and Social

Committee and The Committee of the Regions, COM (2005) 596 final, 22 November

(Brussels: CoEC), available at http://eur-lex.europa.eu/ (accessed 18.5.2010).

—, (2006). Europeans and their Languages, Special Eurobarometer 243, Wave 64.3, TNS Opinion

\& Social. Available at http://ec.europa.eu/public_opinion/archives/ebs/ebs_243_en.pdf (accessed 7.3.2011).

CoEC Eurobarometer 44.0 (1995). (Brussels: European Commission) (electronic material).

- 47.0 (1997). (Brussels: European Commission) (electronic material).

- 50.0 (1998). (Brussels: European Commission) (electronic material).

- 54LAN (2000). Special Survey on Language. (Brussels: European Commission) (electronic material).

- 64.3 (2005). (Brussels: European Commission) (electronic material).

Coleman, J. A. (2009) 'Why the British do not Learn Languages: Myths and Motivation in the United Kingdom’, Language Learning Journal 37.1: 111-27.

Eurobarometer see CoEC Eurobarometer.

Gerhards, J. (2008). 'Transnationales linguistisches Kapital der Bürger und der Prozess der europäischen Integration', Berliner Studien zur Soziologie Europas 17. 
Ginsburgh, V., I. Ortuño-Ortín and S. Weber (2007). 'Learning Foreign Languages: Theoretical and Empirical Implications of the Selten and Pool Model', Journal of Economic Behavior \& Organization 64: 337-47.

Grin, F. (2003). 'Language Planning and Economics', Current Issues in Language Planning 4.1: 166.

Hjorth-Andersen, C. (2006). 'The Relative Importance of the European Languages', Paper presented at the 14th International Conference of the ACEI, Vienna, 6-9 July.

Ikonomu, D. M. (2008). Mehrsprachigkeit und ihre Rahmenbedingungen.

Fremdsprachenkompetenz in den EU-Ländern (Bern: Peter Lang).

Kelly, M. (2009). A Third Space for Europe. Intercultural Communication in European Language Policy', European Journal of Language Policy 1.1: 1-20.

Kraus, P. (2008). A Union of Diversity. Language, Identity and Polity-Building in Europe (Cambridge: Cambridge University Press).

Labrie, N., and C. Quell (1997). 'Your Language, my Language or English? The Potential Language Choice in Communication among Nationals of the European Union', World Englishes 16.1: 3-26.

Laitin, D. (1988). 'Language Games', Comparative Politics 20.3: 289-302.

_, (1993). 'The Game Theory of Language Regimes', International Political Science Review 14.3: 227-39.

Macaro, E. (2008). 'The Decline in Language Learning in England: Getting the Facts Right and Getting Real', Language Learning Journal 36.1: 101-108.

Phillipson, R. (2003). English-Only Europe? Challenging Language Policy (London and New York: Routledge).

-, (2008). 'Lingua franca or lingua frankensteinia? English in European Integration and Globalisation', World Englishes 27.2: 250-67.

Pietiläinen, J. (2007). 'Evoluo de lingvoscio en Eŭropa Unio. Al nur-Angla aŭ plurlingva Eŭropo', Language Problems and Language Planning 31.3: 257-79.

Quartremer, Jean: No taxation without translation. Coulisses de Bruxelles, UE. 3.10.2010. Un blog de Libération.fr http://bruxelles.blogs.liberation.fr/coulisses/2010/10/no-taxation-withouttranslation-.html (accessed 18.10.2010).

Reagan, T. (2004). “"Don’t Know Much about the French I Took”: A Contemporary Case for Second Language Study in the Liberal Arts', Arts and Humanities in Higher Education 3.2: 229-39.

Selten, R., and J. Pool (1991). 'The Distribution of Foreign Language Skills as a Game Equilibrium', in R. Selten (ed.), Game Equilibrium Models, Vol. 4 (Berlin: Springer), pp. 6484.

—, (1995). Enkonduko en la Teorion de Lingvaj Ludoj. Ĉu mi lernu Esperanton? Einführung in die Theorie sprachlicher Spiele. Soll ich Esperanto lernen? (Berlin and Paderborn: Institut für Kybernetik).

Swaan, A. de (1993). 'The Evolving European Language System: A Theory of Communication Potential and Language Competition', International Political Science Review 14.3: 241-55. 
Tender, T., and T. Vihalemm (2009). "“Two Languages in Addition to Mother Tongue" - Will This Policy Preserve Linguistic Diversity in Europe?', Trames 13.1: 41-63.

Truchot, C. (2002). Key Aspects of the Use of English in Europe (Strasbourg: Council of Europe). Van Els, T. (2005). 'Multilingualism in the European Union', International Journal of Applied Linguistics 15.3: 263-81.

van Parijs, P. (2004). 'Europe’s Linguistic Challenge', Archives européennes de sociologie, 45.1: $113-54$.

Wright, S. (2009). 'The Elephant in the Room: Language Issues in the European Union', European Journal of Language Policy 1.2: 93-120.

\section{Résumé}

Le présent article analyse les résultats de cinq enquêtes Eurobaromètre (1995, 1997, 1998, 2000 et 2005) destinées à mesurer quelles sont les langues que les Européens considèrent les plus utiles à connaître. La plupart des Européens pensent que l'anglais est le plus utile, suivi par le français et l'allemand. Au cours de la dernière décennie, la popularité du français et de l'allemand en tant que langues utiles a diminué de façon significative, tandis que l'anglais reste apprécié de tous comme la langue la plus utile. Le français et l'allemand ont perdu de leur popularité, en particulier parmi les personnes qui ne les parlent pas comme langue étrangère.

D'autre part, l'espagnol, le russe et d'autres langues (il s'agit souvent des langues des pays voisins, des langues minoritaires ou de la deuxième langue officielle du pays en question) ont maintenu ou même surpassé leur ancien niveau de popularité. L'opinion sur l'utilité des langues varie en fonction de la connaissance des langues du répondant, de son niveau d'éducation et de sa profession. Notre article analyse ces différences, et examine leur impact sur l'étude des langues étrangères et sur l'avenir de la pratique des langues étrangères en Europe.

Mots clés : langues étrangères, Union européenne, opinion publique, langues utiles, anglais, français, allemand 